\title{
Nanodiagnostic Tools in Plant Breeding
}

\author{
Kamel Ahmed Abd-Elsalam ${ }^{1,2 *}$ and Mousa A. Alghuthaymi ${ }^{3}$ \\ ${ }^{1}$ Plant Pathology Research Institute, Agricultural Research Center (ARC), Giza, Egypt \\ ${ }^{2}$ Unit of Excellence in Nano-Molecular Plant Pathology Research (ARC), Giza, Egypt \\ ${ }^{3}$ Biology Department, Science and Humanities College, Alquwayiyah, Shaqra University, Saudi Arabia
}

\section{Editorial}

A new plant variety, with better yield, disease resistance and quality traits, improve agricultural productivity for a growing global population. The traditional plant breeding procedures take many years. Nano genomics-based methods have enabled breeders greater precision breeding have opened up exciting new opportunities for selecting and transferring genes, which has not only reduced the time needed to eliminate unnecessary genes, but has also allowed the breeder to access useful genes from distant plants.

Nanodiagnostic tools similar to microfluidics, nanomaterials, bioanalytical nanosensors, etc. has the potential to solve many more problems related to plant health, production, and prevention and can possibly be used in living plants in field-based assays for transgene expression [1]. This is due to the fact that it enables nanoparticles, nanofibers, and nanocapsules to carry foreign DNA and chemicals that change genes [2]. However, many plant genomes are complex, de novo sequencing with next-generation sequencing technologies is a process fraught with difficulties that then create roadblocks to the employment of these genome sequences for crop enhancement [3]. Nanotechnology can specifically target specific plant pathology problems in agriculture such as in plant-pathogen interactions and provide new techniques for crop disease management [4]. For instance introduction of resistance genes in plant cells using Nano tools may lead to development of resistant varieties which will minimize expenses on agrochemicals required for disease control [5]. Nanodiagnostic tools uses include nanoparticle-mediated gene or DNA transfer in crops for the improvement of disease-resistant cultivars [6].

\section{Transgene Nanovehicles}

The transfer of genes to the target plant cells has been accomplished through the use of a variety of nanotools, including nanoparticles that encapsulate and deliver DNA to target cells, in addition to nanostructured surfaces that capture and release DNA to cells [4]. Nanoparticles are used to transfer DNA and drugs into animal cell and tissues by the process of endocytosis [7], but the use of nanoparticles for DNA delivery in plants was not possible because the plant cell possess an inflexible cell wall. The nanoparticles which can be used for DNA delivery are zinc, starch, calcium phosphate, carbon materials, silica, gold, magnetite, strontium phosphate, magnesium phosphate and manganese phosphate [8]. ZnS nanoparticles are considered as a desirable gene transporter to deliver DNA into intact plant by using ultrasound-mediated technique [9]. The honey-comb-like mesoporous silica nanoparticles (MSN) system with $3 \mathrm{~nm}$ particle size that can carrier DNA and chemicals into isolated plant cell and leaves. They loaded the MSN with the gene and the chemical inducer and capped the ends with gold nanoparticles to keep the molecule from leaching out. Uncapped the gold nanoparticles released the chemical and triggers the gene expression in plant under controlled release conditions [2]. Carbon coated iron nanoparticles was inserted inside the internal hallow of the leaf petiole of pumpkin. Different type of microscopic methods were used to visualize and follow the transport and deposition of nanoparticles, as well as to verify the possibility of concentrating nanoparticles into targted area of plant using small magnet [10]. The fluorescent labeled starch-nanoparticles can be used as plant transgenic vehicle, the nanoparticle biomaterial was designed in such a way that it binded the gene and transported it across the cell wall of plant cells by inducing the formation of transient membrane pores in cell wall, cell membrane and nuclear membrane by using ultrasound method [11].

Some challenging reports on Quantum Dots-mediated gene delivery have been studied, for example the delivery of plasmid DNA [12] into the animal cells, and stable transfection and high expression efficiency were obtained, which have laid a good foundation for the application of QDs in plant genetic transformation. The ability of carbon nanotubes to penetrate intact plant cell wall and cell membrane has already been reported. Cellular uptake of SWCNT/fluo-rescein isothiocyanate and SWNT/DNA conjugates revealed the ability of nano-tubes to act as nanotransporters in walled plant cells [13]. Polyamidoamine (PAMAM) dendrimer-DNA offered methods for transferring a molecule of interest into a plant cell having a cell wall. Micro-injection with Carbon Nanofibers (CNFs) containing foreign DNA has been used to genetically modify golden rice enriched with extra vitamin A [14]. The current methods are provided for genetically or otherwise modifying plants and for treating or preventing disease in plant cells containing a cell wall [15].

\section{Nanopore-based Technologies}

Current advances in genomics including DNA sequencing is the most important tools in plant breeding and biotechnology. Quick developments in Next Generation Sequencing (NGS) technologies over the last decade have opened up many new chances to discover the relationship between genotype and phenotype with greater resolution than ever before. While it is likely that 3rd Generation systems will soon become widespread in plant genomics research, there has also been progress toward nanopore-based DNA sequencing. Nanopore systems are based on electronic detection of DNA sequence and have the potential of low sample preparation work, high speed, and low cost [16]. These advances are a substantial step forward in improving this inexpensive and potentially more rapid alternative to next-generation sequencing technologies (Figure 1) [17]. The knowledge of genomic organization, diversity and function of genes in crops needs to an understanding of plant biology [18].

*Corresponding author: Kamel Ahmed Abd-Elsalam, Plant Pathology Research Institute, Agricultural Research Center (ARC), Giza, Egypt, Tel: 002 01091049161; E-mail: abd-elsalam.k.a@post.com

Received: December 08, 2014; Accepted December 10, 2014; Published December 13, 2014

Citation: Abd-Elsalam KA, Alghuthaymi MA (2014) Nanodiagnostic Tools in Plant Breeding. J Plant Pathol Microb 5: e107. doi:10.4172/2157-7471.1000e107

Copyright: (c) 2014 Abd-Elsalam KA, et al. This is an open-access article distributed under the terms of the Creative Commons Attribution License, which permits unrestricted use, distribution, and reproduction in any medium, provided the original author and source are credited. 
Citation: Abd-Elsalam KA, Alghuthaymi MA (2014) Nanodiagnostic Tools in Plant Breeding. J Plant Pathol Microb 5: e107. doi:10.4172/2157$7471.1000 \mathrm{e} 107$

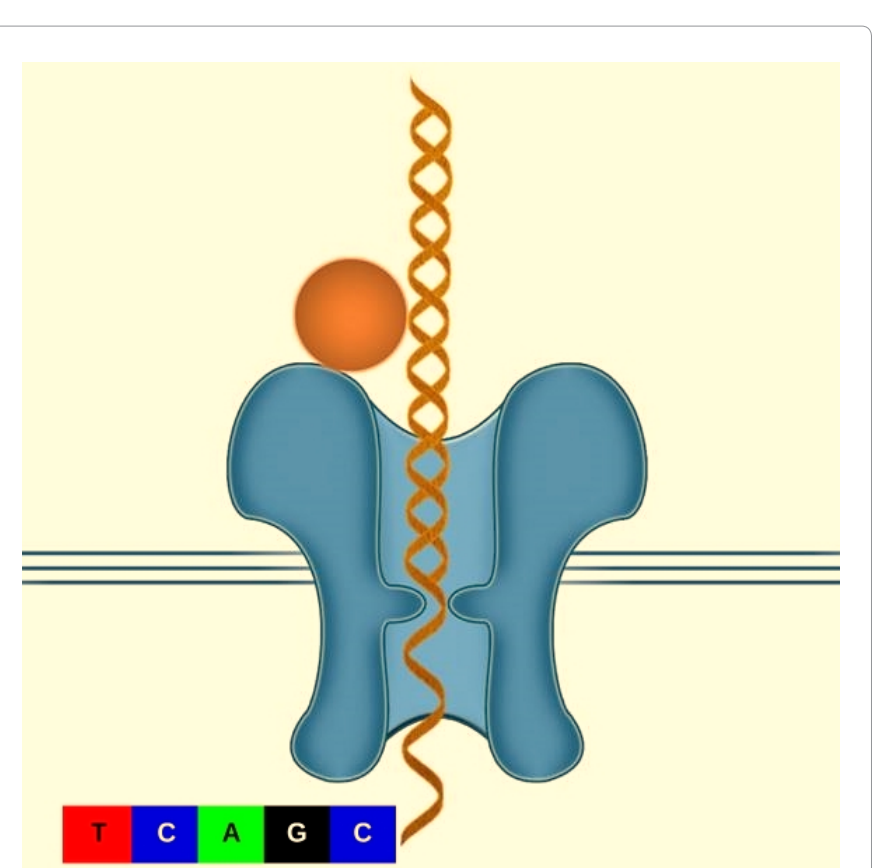

Figure 1: Diagram of a DNA molecule travelling through a protein nanopore [17].

Plant breeders and phytopathologist are needed who can apply nanogenomics and develop nanodiagnostic technologies to accurately advance the improvement process and take advantage of the potential of genomics. Nanotechnology presents new plant gene delivery and nanopore DNA sequencing systems to improve crop resistance against plant diseases and increase food security.

\section{References}

1. Stewart Jr CN (2005) Monitoring the presence and expression of transgenes in living plants. Trends Plant Sci 10: 390-390.

2. Torney F, Braine GT, Victor SY, Kan W (2007) Mesoporous silica nanoparticles deliver DNA and chemicals in to plants. Nat Biotech 2: 295-300.

3. Jackson SA, Iwata A, Lee S-H, Schmutz J, Shoemaker R (2011) Sequencing crop genomes: approaches and applications. New Phytologist 191: 915-925.
4. Rai M, Deshmukh S, Gade A, Abd-Elsalam KA (2012) Strategic nanoparticles mediated gene transfer in plants and animals - a novel approach. Curr Nanoscience, 8: 170-179.

5. Taylor TM, Davidson PM, Bruce BD, Weiss J (2005) Liposomal nanocapsules in food science and agriculture. Crit Rev Food Sci Nutr 45: 587-605.

6. Sekhon BS (2014) Nanotechnology in agri-food production: an overview. NanotechnolSci Appl 20147: 31-53

7. Luo D, Han E, Belcheva N, Saltzman WM (2004) A self-assembled, modular DNA delivery system mediated by silica nanoparticles. J. Control, release, 35 333-341.

8. Sokolova V, Epple M (2008) Inorganic nanoparticles as a carrier for nucleic into cell. Angew Chem Int Ed. 47: 1382-1395.

9. Yu-qin FU, Lu-hua LI, Pi-wu WANG, Jing QU, Yong-ping FU, et al. (2012) Delivering DNA into plant cell by gene carriers of $\mathrm{ZnS}$ nanoparticles. Chem Res Chinese Universities 28: 672-676.

10. González-Melendi P, Fernández-Pacheco RF, Cornado MJ, Corredor E Testillano PS, et al. (2008) Nanoparticles as a smart treatment delivery in plants. Assessment of different techniques of microscopy for their visulation in plant tissues. Ann Bio-London. 101: 187-195.

11. Jun L, Feng-Hua W, Ling-ling W, Su-yao X, Chun-yi T, et al. (2008) Preparation of fluorescence starch-nanoparticle and its application as plant transgenic vehicle. J Cent South Uni Technol 15: 768-773.

12. Srinivasan C, Lee J, Papadimitrakopoulos F, Silbart LK, Zhao M, et al. (2006) Labeling and intracellular tracking of functionally active plasmid DNA with semiconductor quantum dots. Mol Ther 14: 192.

13. Liu Q, Chen B, Wang Q, Shi X, Xiao Z, et al. (2009) Carbon nanotubes as molecular transporters for walled plant cells. Nanolett 9: 1007-1010.

14. AZoNano.com. (2013) Nanofibers to be used in drug delivery, gene therapy, crop engineering and environmental monitoring Manchester, UK: AZoM.com Pty. Ltd; 2003

15. Pasupathy K, Lin S, Hu Q, Luo H, Ke PC (2008) Direct plant gene delivery with a poly(amidoamine) dendrimer. Biotechnol J 3: 1078-1082.

16. Branton D, Deamer DW, Marziali A, Bayley H, Benner SA, et al. (2008). The potential and challenges of nanopore sequencing. Nat Biotechnol 26: 11461153

17. Khiyami MA, Almoammar $\mathrm{H}$, Awad YM, Alghuthaymi MA, Abd-Elsalam KA (2014) Plant pathogen nanodiagnostic techniques: forthcoming changes? Biotechnol Biotechnol Equip 28: 775-785

18. Varshney RK, Terauchi R, McCouch SR (2014) Harvesting the Promising Fruits of Genomics: Applying Genome Sequencing Technologies to Crop Breeding. PLoS Biol 12: e1001883. 